\title{
Exopolysaccharides Production and Characterization from Marine-Derived Penicillium commune KP942881.1 with Some Medical Potential Applications
}

\author{
Alaa M.Abou Zied, Eman H.F.Abd El-Zaher, H.A. H. Ibrahim*,Toka A.Hammad ${ }^{\#}$ \\ Botany Department, Faculty of Science, Tanta University, Tanta and "Microbiology \\ Department, Marine Environment Division, National Institute of Oceanography and \\ Fisheries (NIOF), Alexandria, Egypt
}

\begin{abstract}
SEVEN common marine-derived fungi were isolated from different collection sites distributed $\checkmark$ in Eastern and Western harbor of Alexandria, Egypt. The most promising marine-derived fungusproducing exopolysaccharide (EPS) was Penicillium commune (KP942881.1) which was identified according to microscopic morphological features and confirmed genetically by $18 \mathrm{~S}$ rRNA gene. The results of the optimizing conditions for EPS production from marine-derived P. commune showed that $40 \mathrm{mg} / \mathrm{ml}$ of sucrose, $20 \mathrm{mg} / \mathrm{ml}$ of peptone, $\mathrm{pH} 5$ and $3 \mathrm{~cm}$ discs of inoculum size and incubation at $30^{\circ} \mathrm{C}$, for 9 days were the optimal conditions with using static condition for all factors. Three main spectroscopic analyses (FTIR, ${ }^{1} \mathrm{H}$ NMR and HPLC) were employed to characterize the EPS extracted from marine-derived P. commune. ${ }^{1} \mathrm{HNMR}$ analysis of EPS exhibited the presence of $\beta$-galatopyranosyl. The HPLC chromatography showed that the EPS consist of two peaks; raffinose and rhamnose. EPS showed antiproliferative activity at dose $10 \mathrm{mg} / \mathrm{ml}$ where the percentage inhibition of tumor viability cells of colon was $85 \%$. In breast cell (Mcf-7), EPS inhibited $87 \%$ of the tumor cells at dose $10 \mathrm{mg} / \mathrm{ml}$ and also the antiviral activity of EPS of $P$. commune exhibited $22.8 \%$ inhibition.
\end{abstract}

Keyword: Marine-Derived Penicillium commune, Exopolysaccharides, Characterization, Anti-tumor, Antiviral.

\section{Introduction}

There are several groups of microorganisms producing exopolysaccharides (EPSs) with different properties and applications, such as antitumor agents (Chen et al., 2008 and Peng et al., 2003), food packaging materials (Mc Neely et al., 1973), and wound dressing materials (Madla et al., 2005 and Methacanon et al., 2008). In particular, EPS produced by fungi to protect their cells against desiccation, phagocytosis and phage attack, toxic compounds, predation by protozoans, and osmotic stress, as well as in cellular recognition (Vuyst et al., 1999). Marine fungi have proved to be a rich source of new biological natural products. Because of their characteristic properties with reference to temperature, nutrients, competition and salinity, they have developed specific secondary metabolic pathways compared with terrestrial fungi (Liberra \& Lindequist, 1995). Marine filamentous fungi have proved to possess tremendous source of new medicines even at low concentrations of their secondary metabolites, as some recent studies prove too (Swathi et al., 2013 and Sharma \& Gautam, 2017). Fungal EPSs have been recognized as high value bio-macromolecules for the last two decades.

The purpose of the present researchwas to screening marine EPS producing fungi and evaluates the growth factors that might increase the productivity of EPS. Also characterization of EPS by using HPLC, IR and NMR. Antiviral andanti-tumor activities were analyzed in vitro

\section{Materials and Methods}

\section{Sample source}

Marine water samples were collected from eastern and western port of Alexandria. The water samples were collected in sterile tight bottles and transferred to the laboratory in $24 \mathrm{~h}$ of duration.

"Corresponding author:email: saad_toka@yahoo.com 


\section{Isolation of fungi}

The water sample is diluted with different dilution rates. An equal proportion of volume $(\mathrm{v} / \mathrm{v})$ is spread on Potato Dextrose agar medium and was incubated for 34 - days at $25^{\circ} \mathrm{C}$.

\section{Microscopic studies}

The selected strain with full loop is placed at the center of Sabouraud dextrose agar and incubated to obtain colony for morphological identification and were identified microscopically according to the keys of Moubasher (1993).

\section{Molecular identification of selected fungi}

The study of small subunits of ribosomal RNA has revolutionized the classification of microorganisms, both bacteria and fungi. These techniques, based on the PCR amplification of genes coding for rRNAs and sequence comparison. Rapid identification of filamentous fungi was reached using two specific PCR primers sets (Pedersen et al., 1997 and Turenne et al., 1999).

Firstly, DNA was extracted by use protocol of GeneJet Plant genomic DNA purification Kit (Thermo):K0791. Then PCR was run by using Maxima Hot Start PCR Master Mix (Thermo): K0221. The PCR was cleaned up to the PCR product using GeneJETTM PCR Purification Kit (Thermo): K0701. Finally, sequencing to the PCR product on GATC Company was made by use ABI 3730xl DNA sequencer by using forward and reverse primers.

\section{Physiological factors affecting on EPSS production by $P$. commune}

Different experiments were made to select the most favorable conditions for high production of EPSs dry weight.

\section{Effect of shaking/staticcultures}

It was made by using $20 \mathrm{~g} / \mathrm{L}$ glucose and 10 $\mathrm{g} / \mathrm{L}$ peptone liquid media using static and shaked conditions. The medium was adjusted at initial $\mathrm{pH}$ 6. The sterilized flasks were inoculated with fungal disc with $1 \mathrm{~cm}$ in diameter. After inoculation, the media was incubated at $25^{\circ} \mathrm{C}$ for 5 days in static and rotary shaker at 90 and $120 \mathrm{rpm}$.

\section{Effect of different media under static condition}

Four different media; potato dextrose medium, malt medium, glucose peptone medium, Capek's medium have been used. They were inoculated with $1 \mathrm{~cm}$ fungal disc and then incubated at $25^{\circ} \mathrm{C}$ in static incubator for 5 days.

\section{Effect of different temperature degrees}

Different temperature degrees $(20,25,30,35$, and $37^{\circ} \mathrm{C}$ )were tested for 5 days at $\mathrm{pH} 6$ (Elshamy \& Nehad, 2010).

\section{Effect of different $\mathrm{pH}$ values}

The prepared liquid glucose peptone media was adjusted at different initial $\mathrm{pH}$ values $(4,5,6$, 7 , and 8 ) by using $\mathrm{HCL}$ and $\mathrm{NaOH}$ to adjust each of $\mathrm{pH}$ values for selecting the optimum $\mathrm{pH}$ value for high production of EPSs from $P$. commune (Elshamy \& Nehad, 2010).

\section{Effect of different incubation periods}

In order to select the optimum incubation period for high production of EPSs from $P$. commune, five incubation periods $(3,5,7,9$ and 11 days) were carried out (Elshamy \& Nehad, 2010).

\section{Effect of different carbon sources}

In this experiment, the glucose peptone media will be replaced with equimolecular weight concentrations of the following different carbon sources (sucrose, fructose, maltose, CMC and starch). The initial $\mathrm{pH}$ was adjusted at 5. After sterilization, the different flasks were inoculated with fungal disc $1 \mathrm{~cm}$ in diameter. Incubate the inoculated flasks at $30^{\circ} \mathrm{C}$ for 9 days in incubator.

\section{Effect of different nitrogen sources}

Peptone nitrogen source of sucrose peptone medium for EPS was replaced with different nitrogen sources (Yeast extract + peptone, sodium nitrite, sodium nitrate, gelatin, and ammonium chloride) at equimolecular weight. The flasks were inoculated with one disc and then were incubated for 9 days at $30^{\circ} \mathrm{C}$.

\section{Effect of different inoculum size}

The glucose peptone media flasks were adjusted at initial $\mathrm{pH} 5$ for EPSs production. The media were inoculated with different inoculum numbers (one, two, three and four discs) with $1 \mathrm{~cm}$ diameter size. The inoculated media were incubated at $30^{\circ} \mathrm{C}$ for 9 days.

\section{Extraction of EPSS}

The culture filtrate was separated from the mycelia biomass followed by adding 5\% Trichoroacetic acid (TCA) for removing protein (Khalil, 2002) and stored at freezer overnight. The supernatant was mixed with two volumes of $95 \%$ of isopropanol, stirred vigorously overnight at $4{ }^{\circ} \mathrm{C}$. The resultant precipitate was recovered by centrifugation at $3000 \mathrm{rpm}$ for $20 \mathrm{~min}$ (Wu et al., 2008). 


\section{Measurement of carbohydrate content}

The content of EPS was determined by phenol-sulfuric colorimetric method (Dubois et al., 1956) using glucose as standard and measured spectrophotometrically at $490 \mathrm{~nm}$.

Purification of EPSS

Crude EPS were partially purified by dialysis membrane (Berg et al., 2007).

\section{Characterization of EPSs produced by $P$. commune \\ FT-IRanalysis}

Fourier transform-infrared (FT-IR) spectroscopy (FT/IR-4100, Japan) was employed using the $\mathrm{KBr}$ disc for the analysis and detecting of functional groups (Shen et al., 2013).

$N M R$ analysis

The ${ }^{1} \mathrm{H}$ nuclear magnetic resonance (NMR) spectra of exopolysaccharides in DMSO were obtained with $300 \mathrm{MHz}$ Bruker NMR Spectrometer (Central Lab, Faculty of science, Alex University, Egypt) (Kogan et al., 2002).

\section{HPLC analysis}

Exopolysaccharides were hydrolyzed following the method of Chen et al. (2005). Analysis of the carbohydrate in the filtrate was performed by using HPLC, Shimadzu Class-VPV 5.03 (Kyoto, Japan) equipped with refractive index RID-10A Shimadzu detector.

\section{Antitumor activity of EPS from $P$. commune}

The human colon (Caco-2) and breast cancer (MCF-7)were kindly provided by the Regional Center for Mycology \& Biotechnology at Al-Azhar University Cairo Egypt. They grow on RPMI -1640 medium supplemented with $5 \%$ heated Foetal Bovine Serum (FBS), $2 \mathrm{mM}$ glutamine and antibiotics (penicillin 100U/ml, streptomycin $100 \mu \mathrm{g} / \mathrm{ml}$ ), at $37^{\circ} \mathrm{C}$ in humified atmosphere containing $5 \% \mathrm{CO}_{2}$. Exponentially growing cells were obtained by plating $1.5 \times 10^{5}$ cells/ml for human colon (Caco-2) andbreast cancer (MCF-7) 10.75 $\times 104$ cells $/ \mathrm{ml}$ followed by $24 \mathrm{~h}$ of incubation (Monks et al., 1991). The protein-binding dye sulforhodamineB was used to estimated cells growth. The bound stains were solubilized and the absorbances were measured at $492 \mathrm{~nm}$ in plate reader. For each tested compound and cell lines, a dose response curve were obtained and the minimum inhibitory concentration (IC50) cell were calculated as described.

Antiviral activity of EPS from P. commune

Vero cells (derived from the kidney of normal African green monkey) were obtained from American Type Culture Collection (ATCC) and kindly provided by the Regional Center for Mycology \& Biotechnology at Al-Azhar University Cairo, Egypt. Continuous cell line was established by Yasumura \& Kawakita (1963). Vero cells were grown as monolayer in media supplemented with $10 \%$ inactivated fetal bovine serumand the monolayers of $(10,000)$ cells were plated $\left(10^{4}\right.$ cells/ well) in 96-well tissue culture plate and incubated for $24 \mathrm{~h}$ at $37^{\circ} \mathrm{C}$ in a humidified incubator with $5 \%$ $\mathrm{CO}_{2}$ before treatment with the extracts. Different concentrations of Endotoxin (10, 5, 2.5, 1.25, 0.625, 0.312 and $0.156 \mathrm{mg} / \mathrm{ml}$ ) were added to the cell monolayer and the plates were incubated for $48 \mathrm{~h}$ into $\mathrm{CO}_{2}$ incubator at $37^{\circ} \mathrm{C}$ and $5 \% \mathrm{CO}_{2}$. Fifty microliters of MTT reagent was added to each welland after addition of MTT reagent the plates were incubated in dark for $4 \mathrm{~h}$ for the reduction of MTT to form azan. One hundred microliters of DMSO was added to each well to solubilize the purple crystals of formazan and absorbance was measured at $(570 \mathrm{~nm})$. The percentage of cell survival was calculated by the following equation:

$$
\begin{aligned}
& \text { Survival rate } \%=\frac{A \text { sample }-A_{b}}{A_{c}-A_{b}} \times 100 \\
& A_{c}=\text { Negative control } \\
& A_{b}=\text { Blank }
\end{aligned}
$$

Results and Discussion

Isolation of marine-derived fungi

Seven common marine-derived fungi were isolated from different collection sites distributed in Eastern and Western harbor of Alexandria, Egypt. They were coded as; TE1, TE2, TE3, TW1, TW2, TW3, and TW4. They were sub-cultured on potato dextrose medium, and then the isolated colonies were grown on potato dextrose agar plates at $25^{\circ} \mathrm{C}$ and incubated for 5 days. After that time, the plates were maintained at $4^{\circ} \mathrm{C}$ until used. However, they were transferred once every two weeks to maintain availability and stability for extracellular polysaccharides production. It was found that fungus TE2 is the most promising one for EPS production and mycelial growth.

Microscopic investigation for the most promising marine-derived fungus (TE2)

This fungus was identified at Faculty of science, Botany Department; Asyut University and was identified according to the keys of Moubasher (1993). Based on the mycelium and spore morphology studies, this isolate was identified as; Penicillium commune and confirmed by $18 \mathrm{~S}$ rRNA gene. 
Genotypic identification of the most promising marine-derived fungus (TE2)

The most promising marine-derived fungus TE2 which identified previously by microscopic investigation as; Penicillium commune was subjected, moreover, to genotypic identification by $18 \mathrm{~S}$ rRNA gene. The molecular characterization confirmed the same obtained identification and the results are shown in Table 1 after multiple sequence alignment between

TABLE 1. The most closely related species and their percentages of identity. the obtained sequences. Sequencing data were aligned against the 18S rRNA sequences (http://blast. ncbi.nlm.nih.gov/Blast.cgi). It has been found that the fungal isolates TE2 had a 99\% identical counterpart with respect to its $18 \mathrm{~S}$ rRNA sequence and take the accession no. KP942881.1. The most closely related species and the percentages of identity are presented in Table 1.

\begin{tabular}{|c|c|c|c|c|c|c|}
\hline Description & $\begin{array}{l}\text { Max } \\
\text { score }\end{array}$ & $\begin{array}{l}\text { Total } \\
\text { score }\end{array}$ & $\begin{array}{l}\text { Query } \\
\text { cover }\end{array}$ & $\begin{array}{c}E \\
\text { value } \\
\end{array}$ & $\begin{array}{c}\text { Identity } \\
(\%)\end{array}$ & Accession no. \\
\hline $\begin{array}{l}\text { Penicillium commune } \\
\text { EECC-651 }\end{array}$ & 839 & 839 & $86 \%$ & 0.0 & 99 & KР942881.1 \\
\hline $\begin{array}{l}\text { Eupenicillium sp. CS-P/ } \\
\text { F09 }\end{array}$ & 758 & 758 & $84 \%$ & 0.0 & 97 & KF528000.1 \\
\hline $\begin{array}{l}\text { Penicillium expansum } \\
\text { isolate } 2534\end{array}$ & 749 & 749 & $88 \%$ & 0.0 & 95 & FJ008994.1 \\
\hline $\begin{array}{l}\text { Penicillium sp. DY31- } \\
\text { W1304-MS15 }\end{array}$ & 715 & 715 & $86 \%$ & 0.0 & 95 & KM274132.1 \\
\hline Penicillium sp. 386 & 647 & 647 & $89 \%$ & 0.0 & 91 & FJ008987.1 \\
\hline $\begin{array}{l}\text { Penicillium expansum } \\
\text { strain Fi-7 }\end{array}$ & 630 & 630 & $83 \%$ & $6 e-180$ & 92 & GU004268.1 \\
\hline Penicillium sp. PSF 24 & 466 & 466 & $81 \%$ & $2 \mathrm{e}-130$ & 86 & HQ850347.1 \\
\hline $\begin{array}{l}\text { Penicillium paneum JCM } \\
28412\end{array}$ & 438 & 438 & $81 \%$ & $4 e-122$ & 85 & LC 133845.1 \\
\hline $\begin{array}{l}\text { Penicillium paneum JCM } \\
28498\end{array}$ & 359 & 359 & $73 \%$ & $3 e-98$ & 83 & LC 133871.1 \\
\hline Penicillium chrysogenum & 350 & 350 & $80 \%$ & $2 e-95$ & 82 & KT963794.1 \\
\hline
\end{tabular}

Physiological factors affecting EPS production from marine-derived P. commune KP942881.1

Eight factors (static and shaking conditions, media,temperatures, $\mathrm{pH}$ level, incubation period, carbon sources, nitrogen sources and inoculum size) were examined independently on the EPS production from marine-derived $P$. commune.

\section{Effect of static and shaking conditions}

The effect of static and shaking conditions (90 and $120 \mathrm{rpm}$ ) on the mycelial growth and EPS production of $P$. commune KP942881.1 was investigated. From the data presented in Fig. 1, static condition was the suitable condition for high mycelial growth production and EPS of P. commune KP942881.1. The EPS concentration in static condition was $1.250 .134 \pm \mathrm{mg} / \mathrm{ml}$ and mycelial dry weight was $0.3290 .014 \pm \mathrm{g} / 100 \mathrm{ml}$. So, static condition was selected as the most suitable condition for EPS production in the subsequent experiments. This result agreed with Rupérez et al. (1984) who precipitated an extracellular polysaccharide from Penicillium allahabadense statically in liquid medium and Chen et al. (2013 a) who produced EPS from Penicillium griseofulvum statically.
Effect of different media under static condition

Potato dextrose, malt, glucose peptone and Capek's media were used to investigate the EPSs production by P.commune and initial $\mathrm{pH}$ was 6 at constant incubation temperature of $25^{\circ} \mathrm{C}$ (Fig. 2). The maximum EPS production was achieved in GP medium after incubation of 5 days in static incubator which produced $0.3420 .008 \pm \mathrm{g} / 100 \mathrm{ml}$ of mycelial dry weight and $1.660 .155 \pm \mathrm{mg} / \mathrm{ml}$ EPS. This result agreed with Peiqin et al., (2012), who reportd that glucose peptone media with different concentration increased exopolysaccharide production of Berkleasmium sp.

\section{Effect of different temperatures}

The data in Fig 3, it is evident that temperature $30^{\circ} \mathrm{C}$ was the optimum for EPSs production and mycelial growth from $P$. commune. The EPS concentration was $1.42 \pm 0.707 \mathrm{mg} / \mathrm{ml}$ under static condition. Mycelial dry weight was $0.378 \pm 0.04$ $\mathrm{g} / 100 \mathrm{ml}$. Elshamy \& Nehad (2010) proved that $30^{\circ} \mathrm{C}$ was suitable for EPS production by Alternaria alternata and Chen et al. (2013b) reported that $28^{\circ} \mathrm{C}$ was suitable for EPS production by Penicillium commune. 


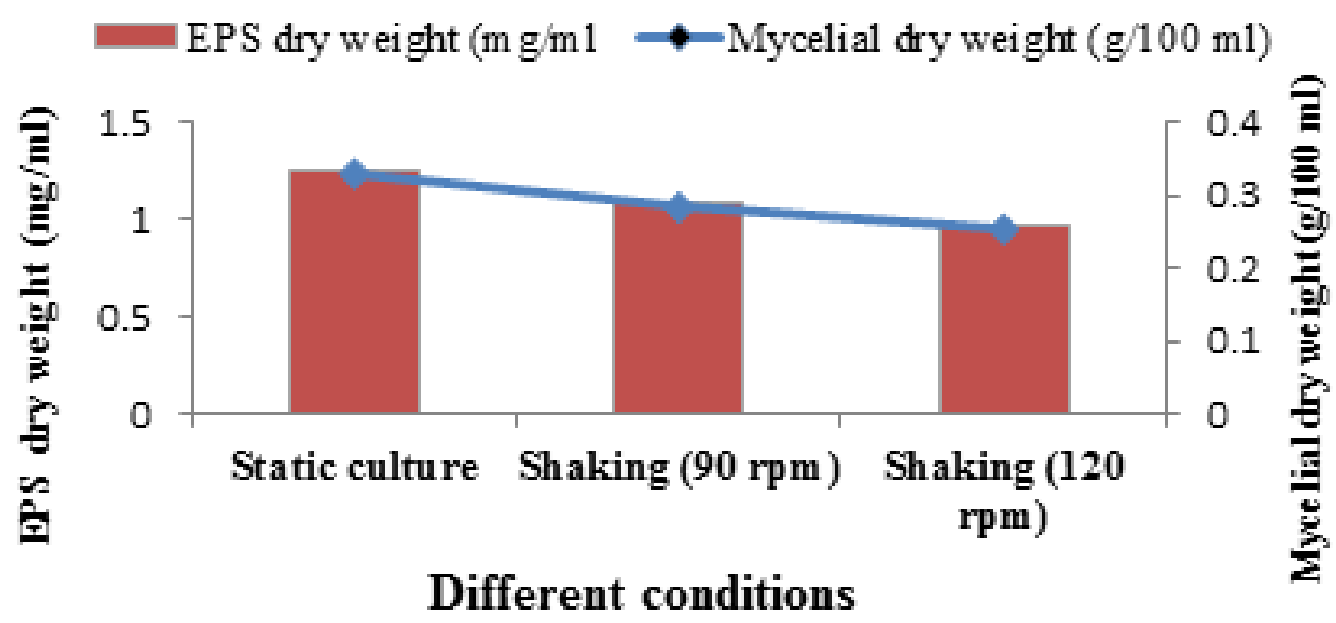

Fig. 1. Effect of static/shaking conditions on mycelial growth and EPS production by $P$. commune

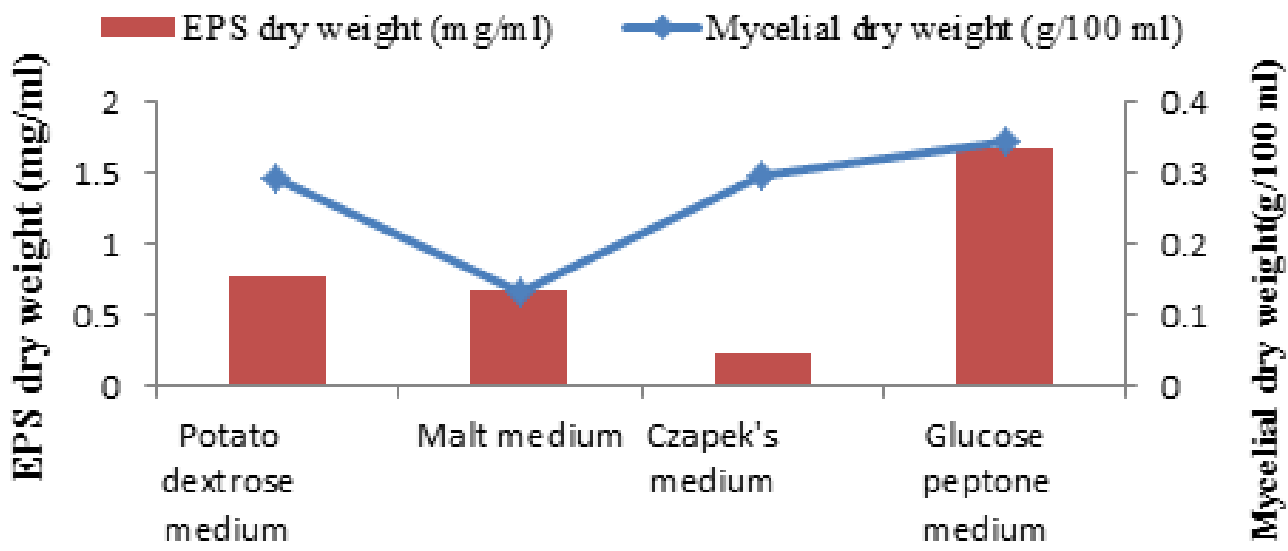

\section{Different media types}

Fig. 2. Effect of different media on mycelial growth and EPS production of $P$. commune under static condition

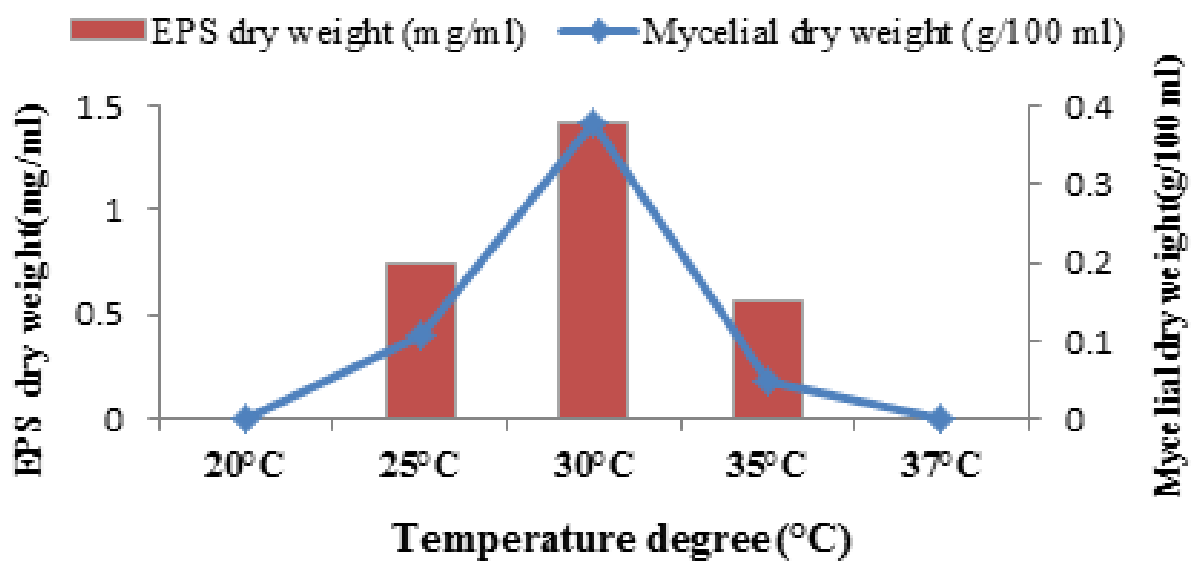

Fig 3. Effect of different temperature on mycelial growth and EPS production of P. commune under static condition 


\section{Effect of different $\mathrm{pH}$ values}

It is evident that $\mathrm{pH} 5$ was the most promising for EPSs production and mycelial growth of $P$. commune. It was clear that there was a gradual decrease in the fungal growth until reaching $\mathrm{pH} 8$ (Fig.4). Therefore, $\mathrm{pH} 5$ was applied for the other experiments. EPS concentration was $1.580 .56 \pm \mathrm{mg} / \mathrm{ml}$ under static condition at $30^{\circ} \mathrm{C}$. Mycelial dry weight was $0.3710 .028 \pm \mathrm{g} / 100 \mathrm{ml}$.NourELdein et al. (2004) reported that $\mathrm{pH} 5$ was optimum for EPS production from Pleurotus pulmonarius. Also, Rong et al. (2010) found that optimum pH for EPS by Hirsultella patwas 5.5

\section{Effect of different incubation period}

The incubation for 9 days was the most promising for EPSs production and mycelial growth from $P$. commune. It was clear that there was a gradual increase in the fungal growth from 3 to 9 days (Fig. 5). So, incubation for 9 days was applied for the other experiments.

The EPS concentration was $1.720 .028 \pm$ $\mathrm{mg} / \mathrm{ml}$ under static condition at $30^{\circ} \mathrm{C}$. Mycelial dry weight was $0.412 \pm 0.0007 \mathrm{~g} / 100 \mathrm{ml}$ and this was consistent with Elshamy \& Nehad (2010) for Alterneria alternata. Chen et al. (2013b) reported that 10 days was suitable for EPS production by Penicillium commune.

\section{Effect of different carbon sources}

The Data in Fig.6 showed that the most suitable carbon source was sucrose. The EPS concentration in sucrose was $1.740 .03 \pm \mathrm{mg} / \mathrm{ml}$ and mycelial dry weight was $0.4020 .003 \pm \mathrm{g} / 100 \mathrm{ml}$. It was reported that sucrose the most suitable carbon source for mycelium growth production in Cordyceps militaris (Park et al., 2001). Yadav et al. (2014) reported that sucrose was the best for exopolysaccharides production by Aureobasidium sp.

\section{Effect of different nitrogen sources}

Different nitrogen sources have performed effect on EPS and biomass production. From Fig.7, it is evident that, EPS concentration using peptone as nitrogen source was $1.810 \pm$ $\mathrm{mg} / \mathrm{ml}$ and fungal growth was $0.3950 \pm \mathrm{g} / 100$ $\mathrm{ml}$. The same conclusions were detected by Fraga et al. (2014) has stated that a higher supply of peptone $\left(4.80 \mathrm{gL}^{-1}\right)$ is needed for maximum EPS production. The highest level of EPS was obtained when peptone was used as a sole nitrogen source by Hirsutella $s p$. (Rong et al., 2010).

\section{Effect of different inoculum size}

It was obvious that three disc sized $1 \mathrm{~cm}$ in diameter from $P$. commune gave high EPS dry weight and high mycelial dry weight. Cultivation of three fungal discs with diameter $1 \mathrm{~cm}$ from tested organism on GP media at static condition for 9 days gave high quantity of $\operatorname{EPS}(1.89 \pm 0 \mathrm{mg} / \mathrm{ml})$ and dry mycelial $(0.420 \pm 0 \mathrm{~g} / 100 \mathrm{ml})$ (Fig. 8). Bae et al. (2000) and Yun et al. (2003) found that inoculum size $(5 \mathrm{~mm})$ of Cordyceps militaris was the most favourable for exopolysaccharide production. Osman et al. (2014) observed that increasing the inoculum size led to a significant increase in growth and polysaccharides production.

\section{Purification of EPSS}

It is used only for purification of exopolysaccharide from impurities to complete characterization and application.

\section{Characterization of EPS obtained from marine-derived P. commune}

Three main spectroscopic analyses (FTIR, ${ }^{1}$ HNMR and HPLC) were employed to characterize the EPS obtained from marinederived $P$. commune.

\section{FT-IR analysis of EPS}

The EPS obtained from $P$. commune was subjected to IR spectroscopy and the FTIR spectra of the EPS exhibited bands at various levels (Fig. 9). Data obtained revealed that adominant absorption that is often attributed to $\mathrm{O}-\mathrm{H}$ stretching vibration at 3361.74 of $\mathrm{O}-\mathrm{H}$ in carboxylic acid which is accompanied with the bands at $2923.88 \mathrm{~cm}^{-1}$ corresponds to $\mathrm{H}$ stretching in carboxylic group. The band at $1740.04 \mathrm{~cm}^{-1}$ approves the stretching vibration of $\mathrm{C}=\mathrm{O}$ carbonyl group of an aldehyde or ketone. The peak at $2933.2 \mathrm{~cm}^{-1}$ identifies the vibration stretching of alkyl hydrogen $\left(\mathrm{CH}_{2}-\right.$ $\left.\mathrm{CH}_{3}\right)$ in aliphatic alkyl group $\left(\mathrm{R}-\mathrm{CH}_{2}-\mathrm{CH}_{3}\right)$. The obvious absorption peaks at $825 \mathrm{~cm}^{-1}$ revealed the existence of $\beta$-galatopyranosyl linked IR spectrum of polysaccharide units as shown in Figure. This result agreed with Sharmila et al. (2014) that the absorption peaks at $825 \mathrm{~cm}^{-1}$ revealed the existence of $\beta$-galatopyranosyl of Syncephalastrum sp. 


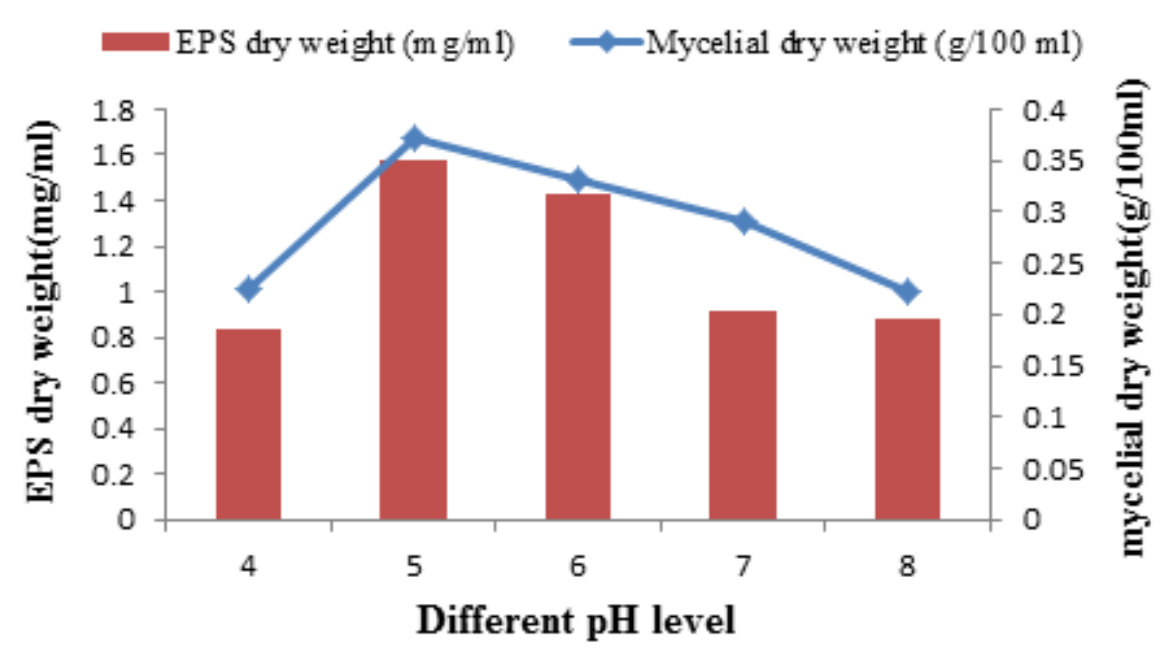

Fig. 4. Effect of different $\mathrm{pH}$ level on mycelial growth and EPS production of $P$. commune under static condition

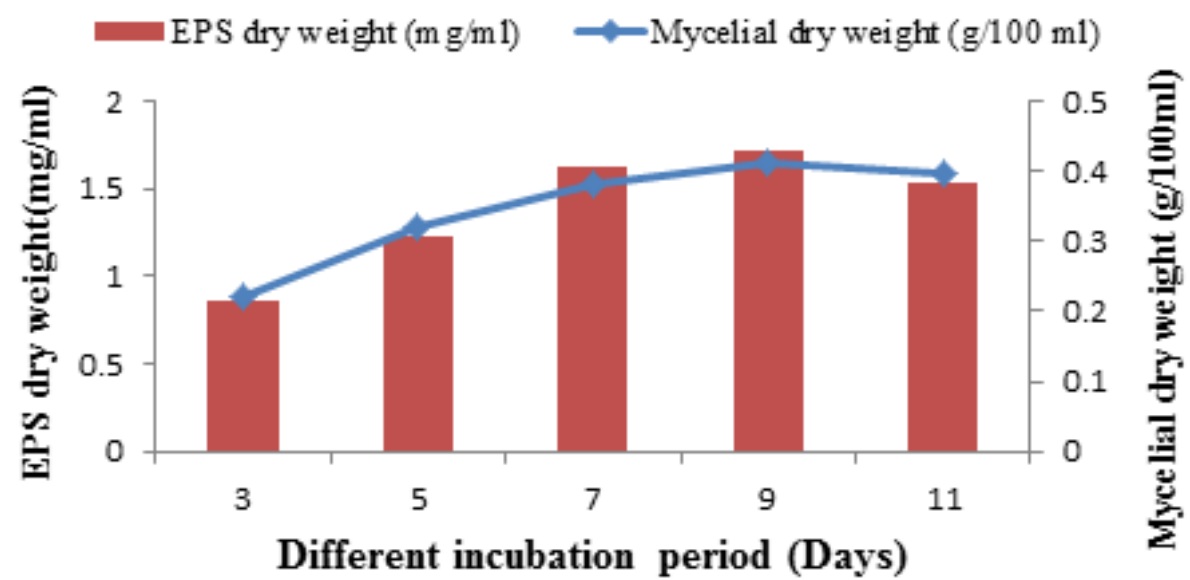

Fig. 5. Effect of different incubation periods onmycelial growth and EPS production of $P$. commune under static condition.

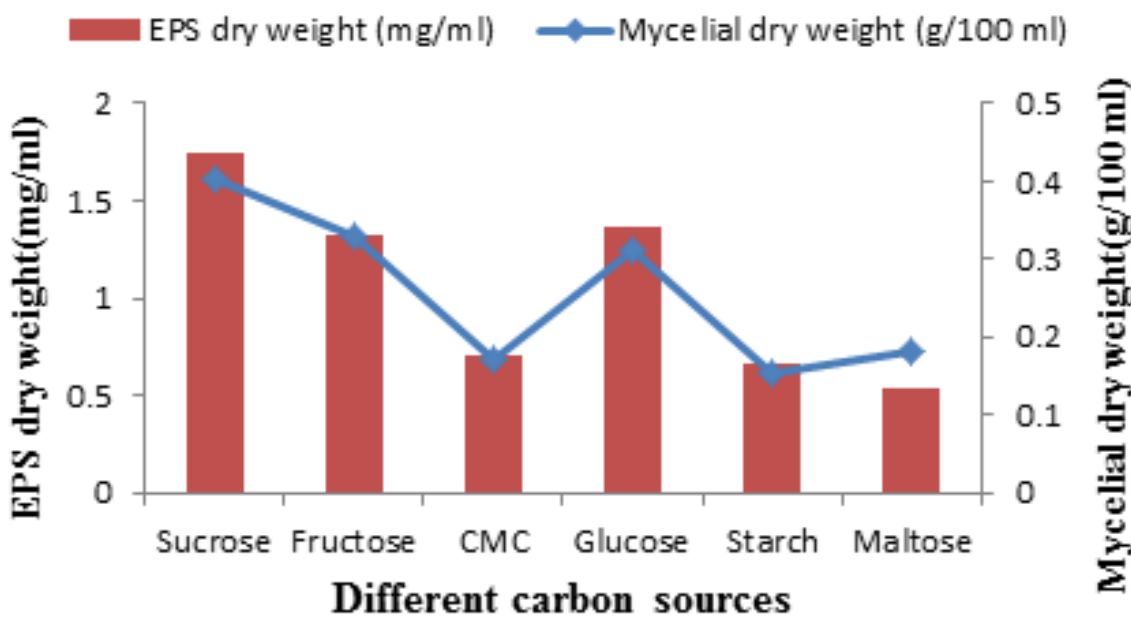

Fig. 6. Effect of different carbon source on mycelial growth and EPS produced by $P$. commune under static condition 


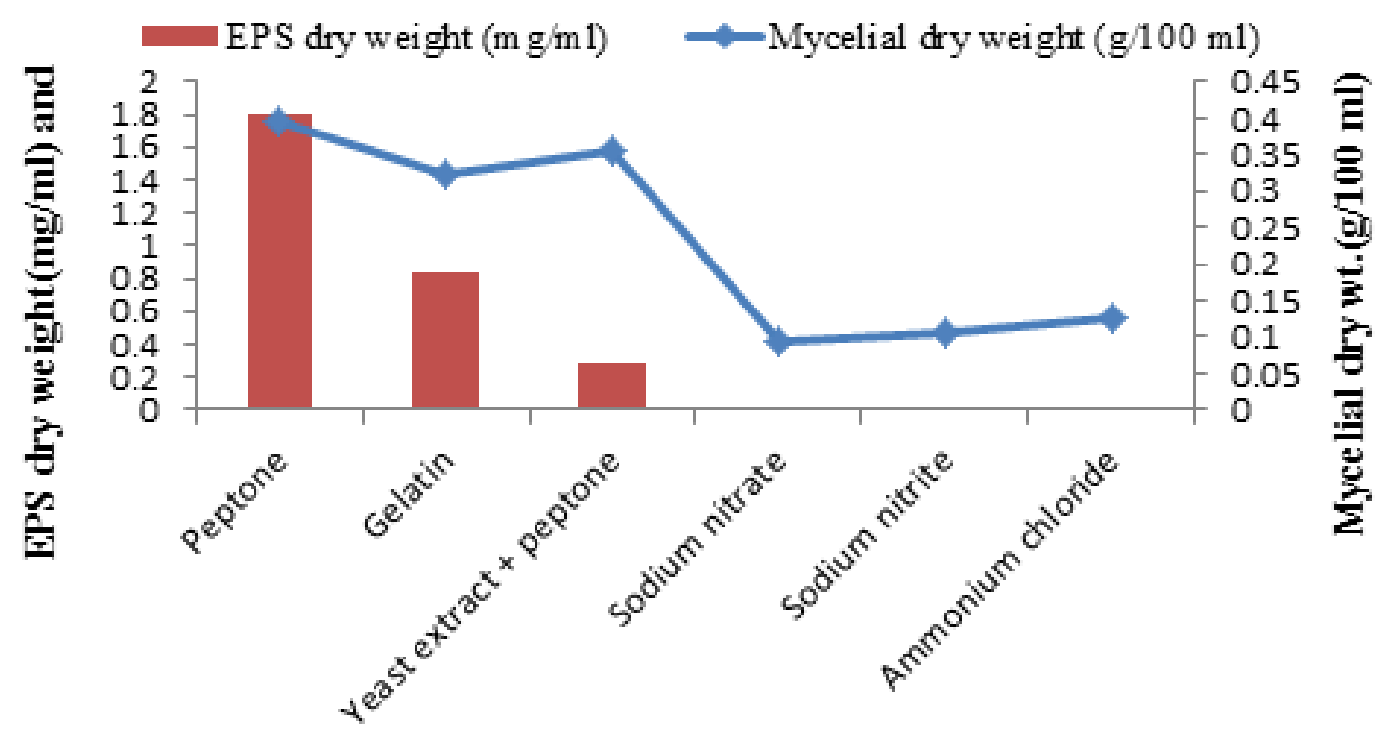

Different nitrogen sources

Fig. 7. Effect of different nitrogen source on mycelial growth and EPS production by $P$. commune TE2 under static condition

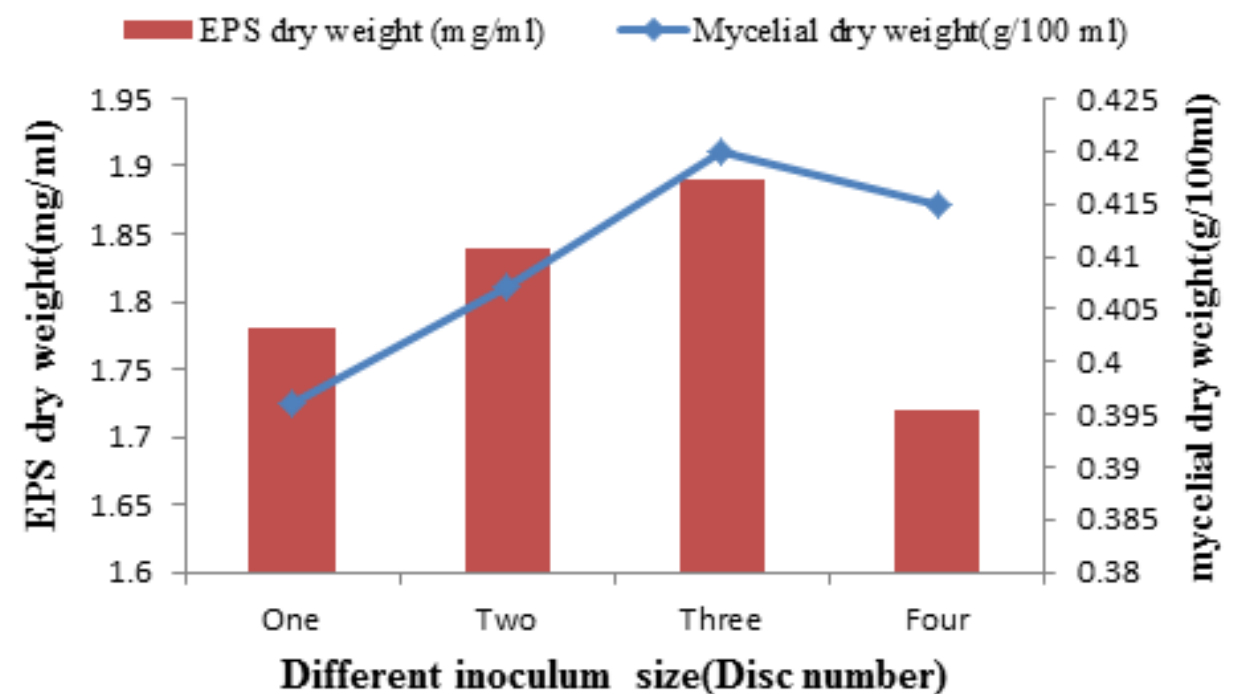

Fig. 8. Effect of different inoculum size (dises number) on mycelial growth and EPS produced by $P$. commune using static culture 


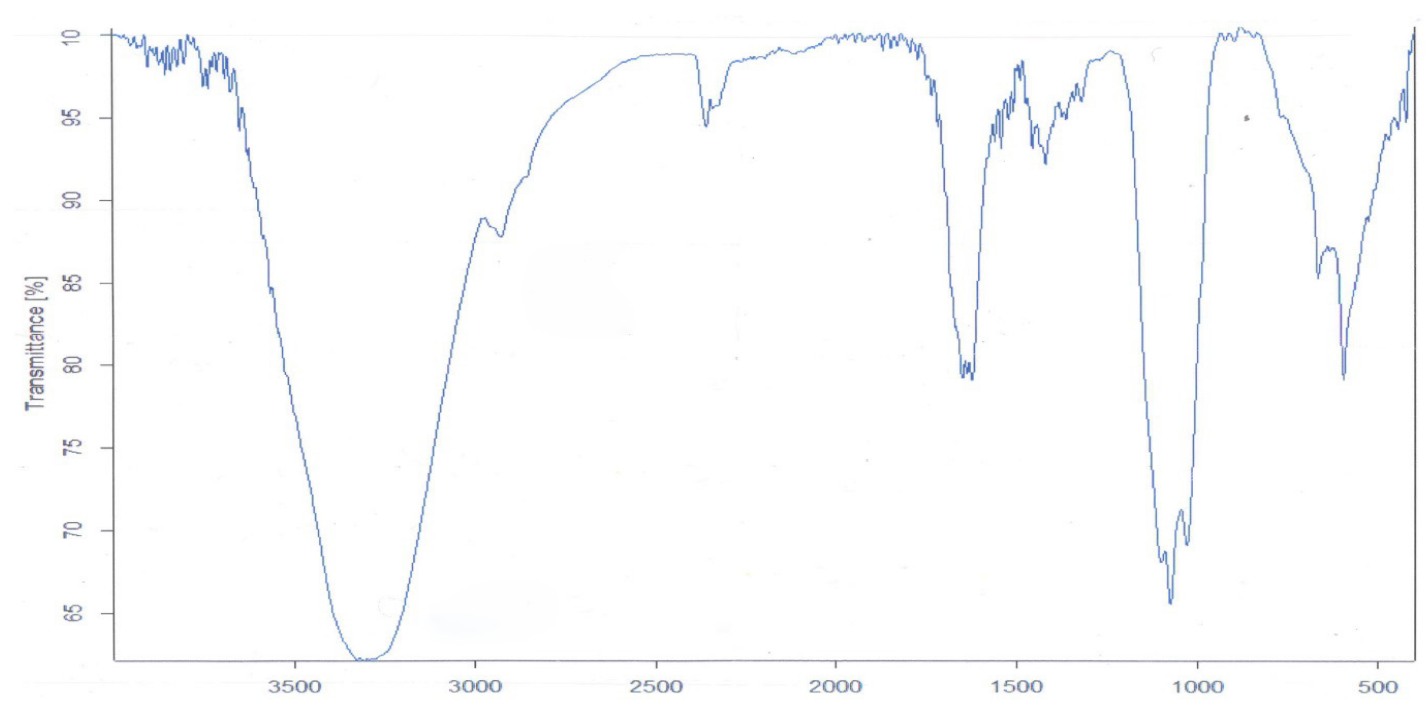

Fig. 9. Chromatogram of FT-IR of EPS produced from P. commune.

${ }^{1}$ HNMR pattern of EPSs

In the ${ }^{1} \mathrm{HNMR}$ spectrum of polysaccharide unit, methoxy carbon was observed in the region, 3.45 to $3.60 \mathrm{ppm}$ integrals. The signals around 3.38 to $3.42 \mathrm{ppm}$ were assigned to methylene proton of $\beta$-D-galactopyronosyl units. Anomericporton $\mathrm{H}-1$ was observed at $5.11 \mathrm{ppm}$, and it was attached with carbon atom $\mathrm{C}-1$. The remaining methane protons were observed at $4.53,3.14$ and $3.12 \mathrm{ppm}$, respectively. ${ }^{1} \mathrm{HNMR}$ spectrum of polysaccharide is shown in Fig.10. This result similar to Sharmila et al. (2014) which indicate the presence of methylene proton of $\beta$-Dgalactopyronosyl units at signals around 3.38 to $3.42 \mathrm{ppm}$ of Syncephalastrum sp. Ahrazem et al. (1999) found that Penicilliumv ermoesenii have similar residues, mainly 2,6-di-O-substituted galactofuranose (2,6)- Galf-(1), and terminal glucopyranose (Glcp-(1), and almost identical "H-NMR spectra .

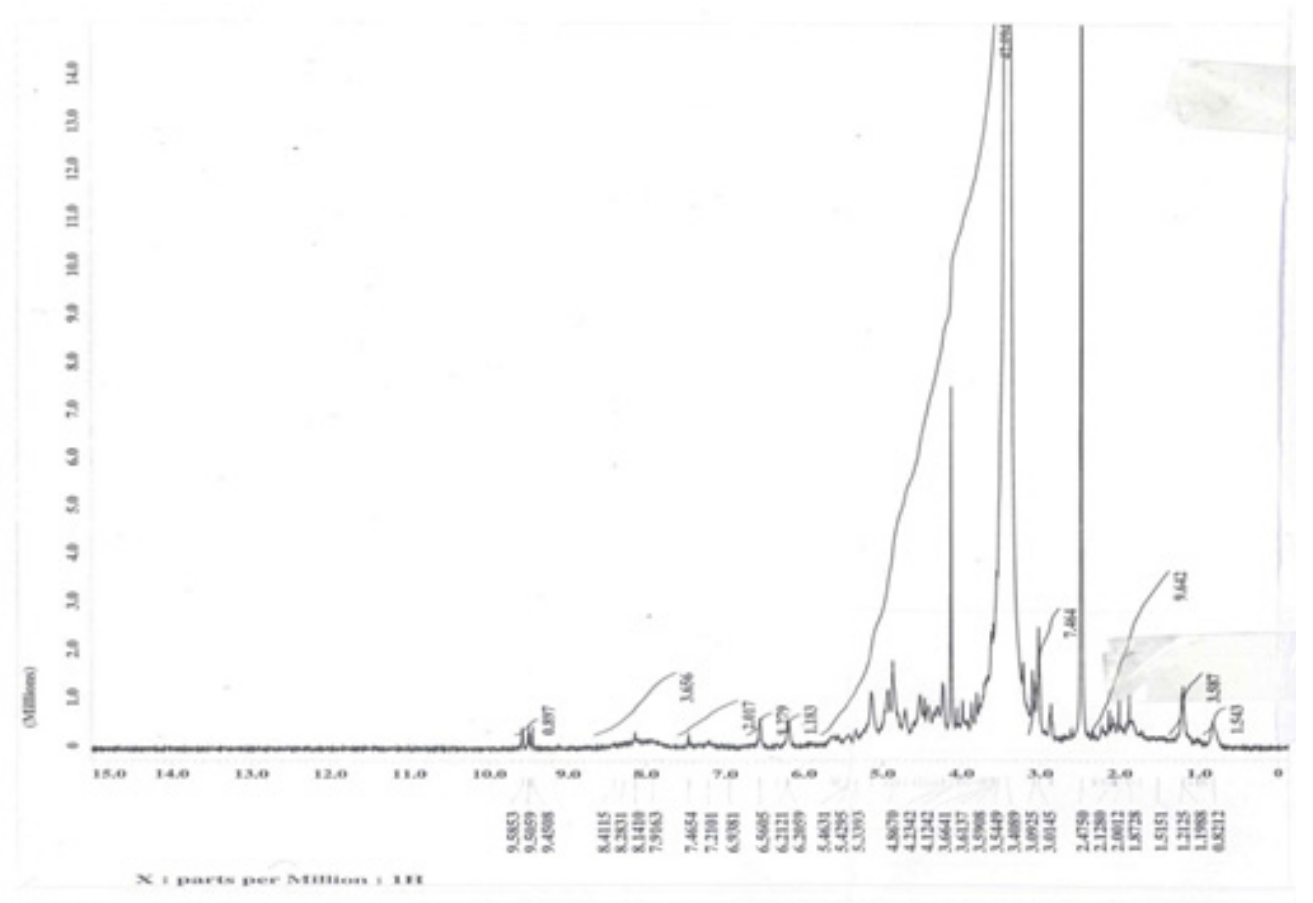

Fig. 10. The ${ }^{1}$ HNMR spectrum of EPSs obtained from P. commune. 


\section{HPLC analysis of EPSS}

The HPLC chromatography of EPS (Fig. 11) showed that the appearance of two peaks the first peak was at retention time $3.5 \mathrm{~min}$ and represented $53.49 \%$ and the second was at retention time $6.1 \mathrm{~min}$ with area $46.51 \%$, which indicated that the EPS is a heteroploysaccharide consisting of raffinose and rhamnose with concentration of 3.542 and $6.104 \mathrm{mg} / \mathrm{g}$, respectively. This result agreed with Sun et al. (2015) who extracted the crude EPS $(0.55 \mathrm{~g} / \mathrm{l})$ from the broth of the coral symbiotic fungus Penicillium sp. Two EPSs, GX11- and GX21- were $93.5 \%$ and $89.7 \%$, respectively the monosaccharide composition differed significantly between the two samples. GX11- contained only glucose, while GX21consisted of mannose, glucose and galactose. Chen et al. (2012) reported polysaccharide were mannopyranose and mannoglucan from Aspergillus versicolor.

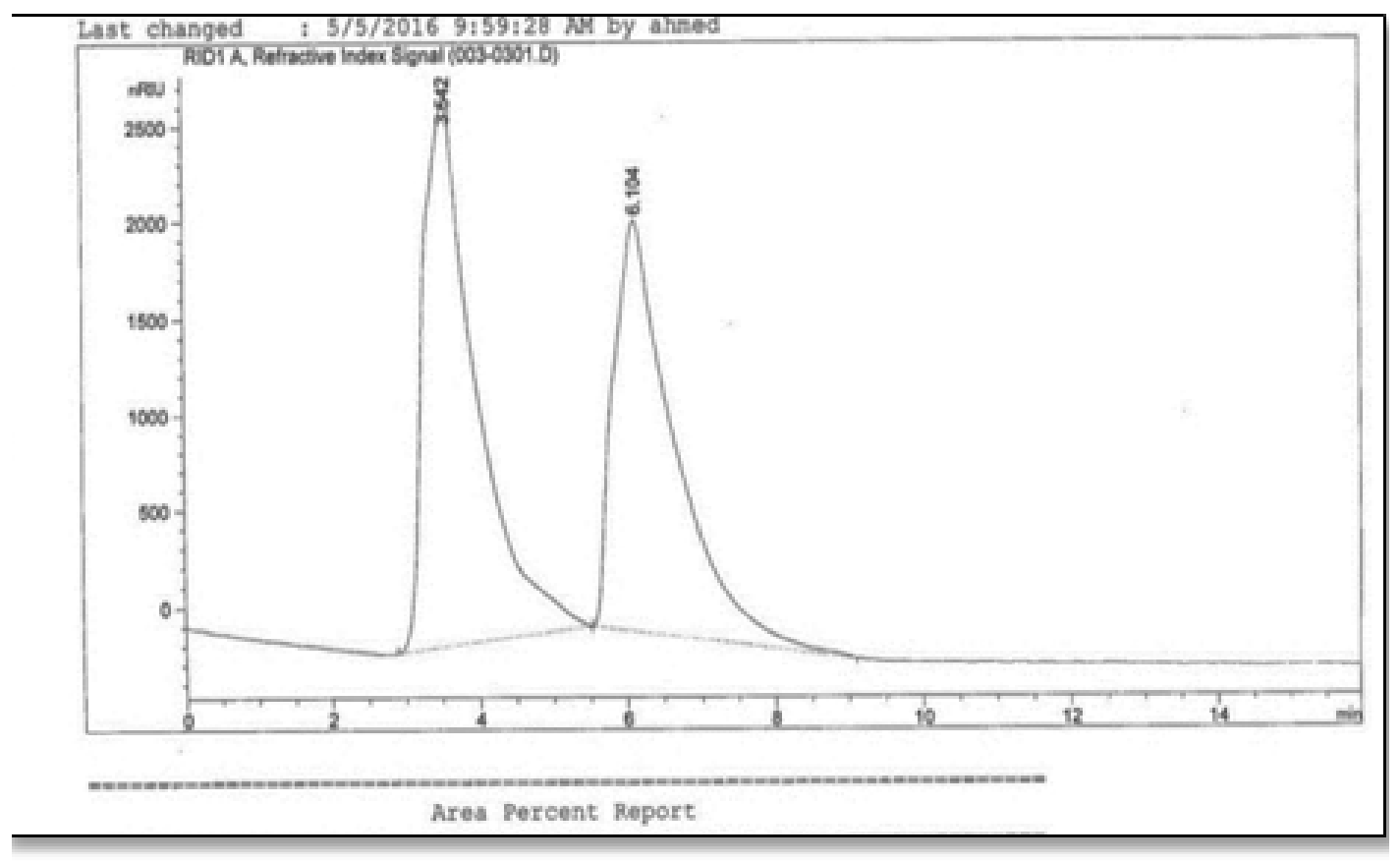

Fig. 11. The HPLC chromatogram of EPS produced from marine-derived $P$. commune.

Anti-tumor activity of EPSs from marine-derived P. commune

In the present study, the growth inhibitory effects of the EPS obtained from marine-derived $P$. commune against human colon cancer cell (Caco-2) and Mcf - 7 breast cancer cells (Mcf-7) were examined. The inhibitory effect was estimated using different concentrations (10, $5,6.25,12.5$, and $25.50 \mu \mathrm{g}$ ) of EPS on both cell lines included. Results showed that the produced EPS exhibited various degree of antitumor effect toward the tested cell lines and increasing concentrations of EPS resulted in increased rates of tumor inhibition. The EPS presented antiproliferative activity at dose $10 \mathrm{mg} / \mathrm{ml}$ where inhibit $85 \%$ of tumor viability cell of colon. In Mcf-7 (breast cell), EPS inhibit $87 \%$ of tumor cell at dose $10 \mathrm{mg} / \mathrm{ml}$. The $\mathrm{IC}_{50}$ for colon was 3.21 $\mathrm{mg} / \mathrm{ml}$, while it was $5.5 \mathrm{mg} / \mathrm{ml}$ for Mcf-7. The effects of EPS on cell line are exhibited in Fig.12.
Liu et al. (2013) also evaluated that cytotoxicities of Penicillium commune EPSs were against five human carcinoma cell lines (Hela, A549, MCF7, HCT116, T24).Latha \& Baskar (2014) approved that polysaccharides of Pleurotus florida-EPS and Hypsizygus ulmarius-EPS had effect against breast cancer cell llines, where it exhibited percentage of cell viability at $66.48 \%$ and $47.63 \%$, respectively.

Anti-viral activity of EPSs from marine-derived P. commune

In the present study, the growth inhibitory effects of the EPS obtained from P. commune against HAV (Hepatitis A Virus) was examined. The HAV was injected to Vero cellcausing $60 \%$ toxicity of Vero cell which represents $100 \%$ of its actual virulent power. By application of EPS crude extract, the toxicity of virus to Vero cell became $46.7 \%$ which represent $77.1 \%$ of viral activity. So, the EPS of $P$. commune exhibited antiviral activity in percentage 
of $22.8 \%$ (Fig.13). Arena et al. (2009) reported that EPS from Bacillus licheniformis and Geobacillus thermodenitrificans are known to interfere with the adsorption and penetration of viruses into host cells, as well as inhibit various retroviral reverse transcriptases.

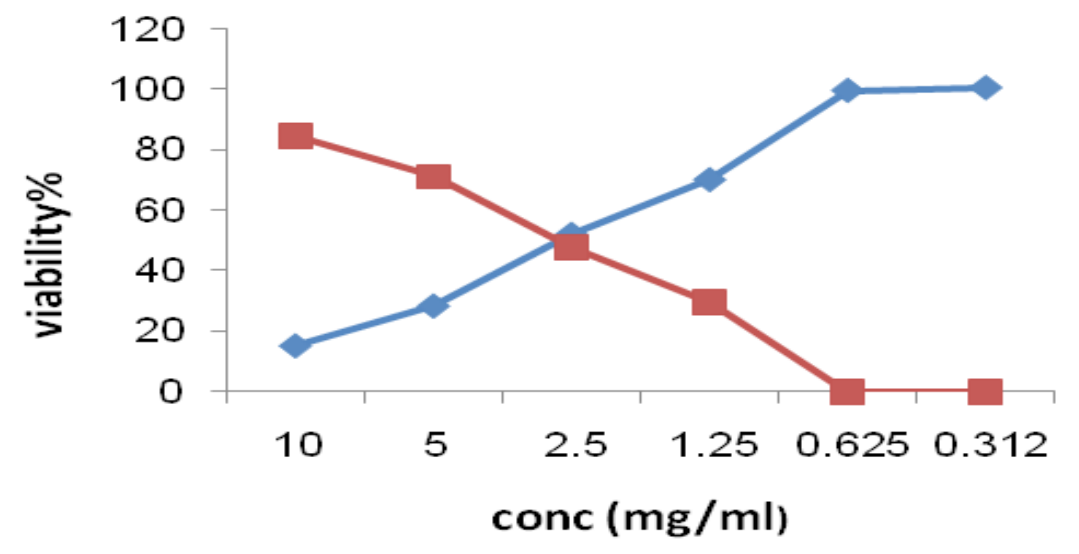

a

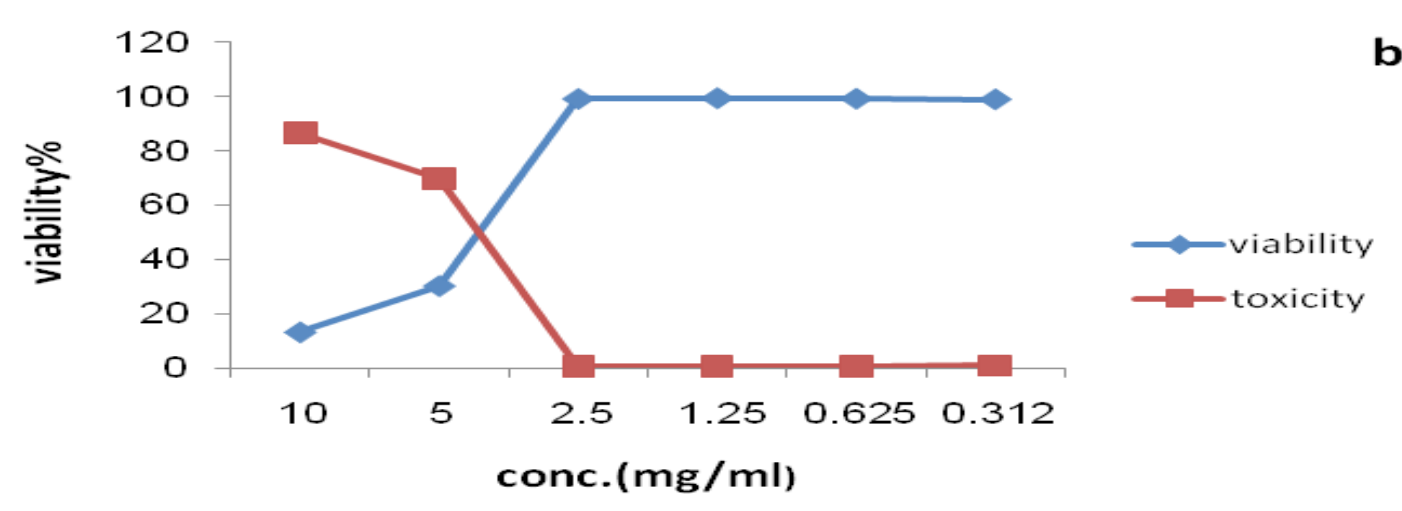

Fig. 12. (a) Effect of different concentrations of EPS on Caco-2 cells, (b) Effect of different concentrations of EPS on Mcf-7 cells

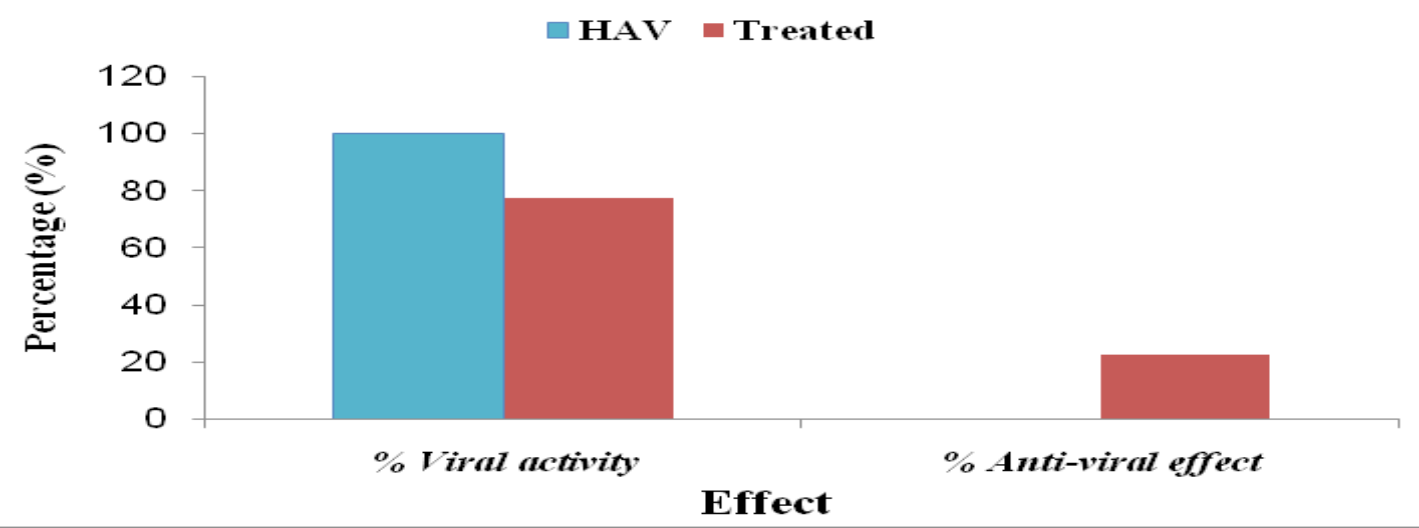

Fig. 13. Effect of different concentrations of EPS obtained from marine-derived $P$. commune on survival HAV (Dilution used was0.625 $\mathrm{mg} / \mathrm{ml}$ ). 


\section{Anti-viral activity of EPSs from marine-derived $P$. commune}

In the present study, the growth inhibitory effects of the EPS obtained from $P$. commune against HAV (Hepatitis A Virus) was examined. The HAV was injected to Vero cell causing $60 \%$ toxicity of Vero cell which represents $100 \%$ of its actual virulent power. By application of EPS crude extract, the toxicity of virus to Vero cell became $46.7 \%$ which represent $77.1 \%$ of viral activity. So, the EPS of $P$. commune exhibited antiviral activity in percentage of $22.8 \%$ (Fig.13). Arena et al. (2009) reported that EPS from Bacillus licheniformis and Geobacillus thermodenitrificans are known to interfere with the adsorption and penetration of viruses into host cells, as well as inhibit various retroviral reverse transcriptases.

\section{Conclusion}

The present study spotlighted on the importance of the EPS from marine-derived $P$. commune KP942881.1. Maximum production of the EPS from $P$. commune was achieved under static condition on sucrose peptone medium at $30^{\circ} \mathrm{C}$ and initial pH 5 for 9 days. The EPS was purified by successive extraction and precipitation by $95 \%$ isopropanol and followed by partial purification with dialysis membrane and FT-IR spectrum analysis of EPS indicated the presence of $\mathrm{C}=\mathrm{O}$, $\mathrm{C}-\mathrm{O}-\mathrm{C}, \mathrm{CH}_{2}$ and $\mathrm{OH}$ groups and also confirmed the presence of $\beta$-galatopyranosyl, ${ }^{1} \mathrm{HNMR}$ analysis of EPS confirmed presence of $\beta$ galatopyranosyl. HPLC chromatography showed that the EPS consisted of two peaks; raffinose and rhamnose. The EPS produced by $P$. communes howed valuable activities for medical purposes such as; antibacterial, antitumor, antiviral, antioxidant and anti-inflammatory.

\section{References}

Ahrazem, O., Gomez-Miranda, B., Prieto, A., Barasoaın, I., Bernabe, M. and Leal, J.A. (1999) Structural characterization of a cell wall polysaccharide from Penicillium vermoesenii: chemotaxonomic application. Can. J. Bot. 77, 961--968.

Arena, A., Gugliandolo, C., Stassi, G., Pavone, B., Iannello, D., Bisignano, G. and Maugeri, T.L.. (2009) An exopolysaccharide produced by Geobacillus thermodenitrificans strain B3-72: antiviral activity on immunocompetent cells. Immunol.Lett. 123, 132-137.

Bae, J.T., Sinha, J., Park, J.P., Song, C.H. and Yun, J.W. (2000) Optimization of submerged conditions for exo-biopolymer production by Paecilomyces japonica. J. Microbiol.Biotechnol.10, 482--487.

Berg, J.M., Tymoczko, J.L. and Stryer, L. (2007) Biochemistry," $6^{\text {th }}$ ed., New York, N.Y., W. H. Freeman, pp. 69.

Chen, S.C., Lu, M.K., Cheng, J.J. and Wang, D.L. (2005) Antiangiogenic activities of polysaccharides isolated from medicinal fungi.FEMS Microbiol. Lett. 249 (2), 247-254.

Chen, W., Zhao, Z., Li, L., Wu, B., Chen, S.F., Zhou, H., Wang, Y. and Li, Y.Q. (2008) Optimization for the production of exopolysaccharide from Fomes fomentarius in submerged culture and its antitumor effect in vitro, Bioresour. Technol. 99, 3187--3194.

Chen, Y., Mao, W. , Yang, Y. , Teng, X. , Zhu, W. , Qi,, X., Chen,Y., Zhao,C., Hou,Y., Wang, C. and Li, N. (2012) Structure and antioxidant activity of an extracellular polysaccharide from coralassociated fungus, Aspergillus versicolor LCJ-54Carbohydrate Polymers, 87, 218-226.

Chen, Y., Mao, W., Wang, B., Zhou, L., Gu, Q., Chen, Y., Zhao, C., Lia, N., Wang, C., Shan, J., Yan, M. and Lin, C. (2013a) Preparation and characterization of an extracellular polysaccharide produced by the deep-sea fungus Penicillium griseofulvum. Bioresour Technol.132, 178-181.

Chen, Y., Mao, W., Wang, J., Zhu, W., Zhao, Ch., Li, N., Wang, Ch., Yan, M., Guo, T. and Liu, X. (2013b) Preparation and structural elucidation of a glucomannogalactan from marine fungus Penicillium commune. CarbohydrPolym., 97 (2), 293-299.

Dubois, M., Gilles ,K.A., Hamilton, J.K., Rebers, P.A. and Smith, F. (1956) Colorimetric method for determination of sugars and related substances. Anal. Chem. 28 (3), 350--356.

ELshamy, A.R. and Nehad, E.A. (2010) Optimization of polysaccharide production by Alterneria alternate. Gate2 Biotech.com, 1(9), 1--6.

Fraga, I., Coutinho, J., Bezerra, R.M., Dias, A.A., Marques, G. and Nunes, F.M. (2014) Influence of culture medium growth variables on Ganodermalucidium exopolysaccharides structural features. Carbohydr.Polym. 111, 936-946.

Khalil, M.A. (2002) Studies on the production of polysaccharides by Azotobacters. M.D. Thesis, Tanta University, Faculty of Science, Department of Botany, Egypt.

Kogan, G., Sandula, J., Korolenko, T.A., Falameeva, O., Poteryaeva, O. , Zhanaeva, S., Levina, O., Filatova,T. and Kaledin, V. (2002) Increased efficiency of Lewis lung carcinoma 
chemotherapy with a macrophage stimulatoryeast carboxylmethylglucan. International Immunopharmacology, 2, 775-781.

Latha, K. and Baskar, R. (2014) Comparative study on the production, purification and characterization of exopolysaccharides from oyster mushrooms, Pleurotus florida and Hypsizygus ulmarius and their applications. P. 8TH Int. Conf. on Mushroom Biology and Mushroom Products (ICMBMP8).

Liberra, K. and Lindequist, U. (1995) Marine fungi: a prolific resource of biologically active natural products? Pharmazie. 50, 583--588

Liu, F.Z., Ren, J.W., Tang, J.S., Liu, X.Z., Che, Y.S., and Yao, X.Z. (2013) Cyclohexanone derivatives with cytotoxicity from the fungus Penicillium commune. Fitoterapia. 87, 78-83.

Madla, S., Methacanon, P., Prasitsil, M. and Kirtikara, K. (2005) Characterization of biocompatible fungiderived polymers that induce IL-8 production, Carbohydr. Polym. 59, 275--280.

McNeely, W.H. and Kang, K.S. (1973) Xanthan and other biosynthetic gums in: Industrial Gums," R.L. Whistler and J.N. BeMiller (Ed.), pp. 473--497, New York: Academic.

Methacanon, P., Madla, S., Kirtikara, K. and Prasitsil, M. (2008) Structural elucidation of bioactive fungiderived polymers, Carbohydr.Polym. 60,199--203.

Monks, A., Scudiero, D., Skehan, P., Shoemaker, R., Paull, K., Vistica, D., Hose, C., Langley, J., Cronise, P., Vaigro-Wolff, A., Gray-Goodrich, M., Campbell, H., Mayo, J. and Boyd, M.( 1991) Feasibility of a high-flux anticancer drug screen using a diverse panel of cultured human tumor cell lines. J. Natl. Cancer. Inst. 83(11), 757-766.

NourELdein, D.M., Fallal, A.A., Shahat, A.T. and Hereher, F.E. (2004) Exopolysaccharides production by Pleurotus pulmonarius: Factors affecting formation and their structures. Pak. J. Biol. Sci. 7, 1078--1084.

Osman, M., Ahmed, W., Hussein, F. and El-sayed, H.. (2014) Endopolysaccharides production and growth of Flammulina velutipes 6 under Submerged Conditions. J. Chem. Bio. Phy. Sci. Sec. B. 4, 3350--3366.

Park, J.P., Kim, S.W., Hwang, H.J. and Yun, J.W. (2001) Optimization of submerged culture conditions for the mycelial growth and exobiopolymer production by Cordyceps militaris.Lett. Appl. Microbiol.33, 76--81.

Pedersen, H. and Hansen, P.V. (1997) Protein-induced fit: the CRP activator protein changes sequence- specific DNA recognition by the CytR repressor, a highly flexible LacI member. $E M B O J . \mathbf{1 6}, 2108$ 2118 .

Peiqin, L.I , Liang, X.u. , Yan, Mou , Tijian, Shan, Ziling, Mao, Shiqiong, Lu, Youliang, Peng, and Ligang, Zhou (2012) Medium optimization for exopolysaccharide production in liquid culture of endophytic fungus Berkleasmium sp. Int. J. Mol. Sci. 13, 1141111426-.

Peng, Y., Zhang, L., Zeng, F. and Xu, Y. (2003) Structure and antitumor activity of extracellular polysaccharides from mycelium, Carbohydr. Polym. 54, 297--303.

Rong, L., Xiao, L.J. and Guan, H.S. (2010) Optimization of mycelium biomass and exopolysaccharides production by Hirsutella sp.In submerged fermentation and evaluation of exopolysaccharides antibacterial activity. African Journal of Biotechnology, 9 (2), 195--202.

Ruperez, P., Gomez-Mirinda, B. and Leal, J.A. (1984) Acidic polysaccharide from Pencillium allahabadens. Can. J. Microbiol. 30, 157--162.

Sharma, S.K. and Gautam, N. (2017) Chemical and bioactive profiling, and biological activities of coral fungi from Northwestern Himalayas.SciRep., doi: 10.1038/srep46570.

Sharmila, K., Thillaimaharani, K.A., Durairaj, R. and Kalaiselvam, M. (2014) Production and characterization of exopolysaccharides (EPS) from mangrove filamentous fungus, Syncephalastrum $\mathrm{sp}$, Afr. J. Microbiol. Res. 8 (21), 2155-2161.

Shen, J.W., Shi, C.W. and Xu, C.P. (2013) Exopolysaccharides from Pleurotus pulmonarius fermentation optimization, characterization and antioxidant activity. Food Technol. Biotechnol.51(4), 520-527.

Sun, K., Chen, Y., Niu, Q., Zhu, W., Wang, B., Li, P. and Ge, X.. (2015) An exopolysaccharide isolated from a coral associated fungus and its sulfated derivative activates macrophages. International Journal of Biological Macromolecules., http:// dx.doi.org/10.1016/j.ijbiomac.2015.11.001.

Swathi, J., Narendra, K., Sowjanya, K.M. and Krishna Satya, A. (2013) Isolation, identification \& production of bioactive metabolites from marine fungi collected from coastal area of Andhra Pradesh, India. J Pharm Res. 6, 663--666.

Turenne, C.Y., Sanche, S.E., Hoban, D.J., Karlowsky, J.A. and Kabani, A.M. (1999) Rapid identification of fungi by using the ITS2 genetic region and an 
automated fluorescent capillary electrophoresis system .J Clin. Microbiol. 37, 1846--1851.

Vuyst, L. and Degeest, B. (1999) Heteropolysaccharides from lactic acid bacteria, FEMS Microbiol. Rev. 23, 153-177.

Wu, Y.C., Liang, Z.C., Lu, C.P. and Wu, S.H. (2008) Effect of carbon and nitrogen sources on the production and carbohydrate composition of exopolysaccharide by submerged culture of Pleurotus citrinopileatus. J. Food Drug Anal. 16 (2), 61--67.

Yadav, K.L., Rahi, D.K. and Soni, S.K. (2014) An indigenous hyperproductive species of
Aureobasidium pullulans RYLF-10: influence of fermentation conditions on exopolysaccharide (EPS) production. Appl. Biochem. Biotech. 172 (4), 18981908

Yasumura, Y. and Kawakita, Y. (1963) Studies on SV40 in tissue culture - preliminary step for cancer research in vitro. Nihon Rinsho. Article in Japanese. 21, 1201-1215.

Yun, Y., Han, S., Lee, S., Ko, S., Lee, C., Ha, N. and Kim, K. (2003) Anti-diabetic effects of CCCA, CMESS, and cordycepin from Cordyceps militaris and the immune responses in streptozotocin-induced diabetic mice. Nat Prod Sci. 9 (4), 291-298.

(Received 16/4/2017 accepted 10/6/2017)

\title{
انتاج عليد التسكر ووصفه من الفطر البحرى البينيسيليوم كومينى KP942881.1 مع بعض تطبيقاته الطبيه
}

\author{
علاء مصطفى ابو زيد، ايمان حسن فتحى عبد الظاهز ، حسن عبد الله حسن ابراهيم* و تقى احمد حماد

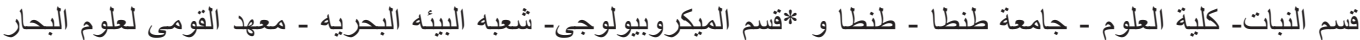

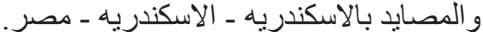

تم عزل سبعة فطريات بحريه من ميناء الإسكندرية الشرقى والغربى في مصر. وقد وجد أن أكثر الفطريات البحرية الواعدة

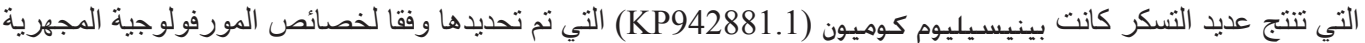

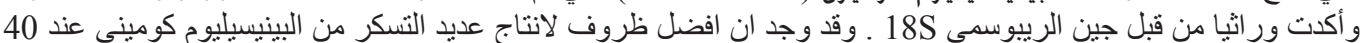

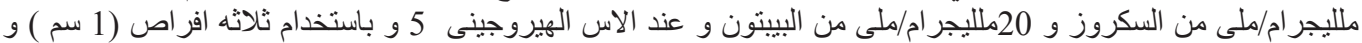

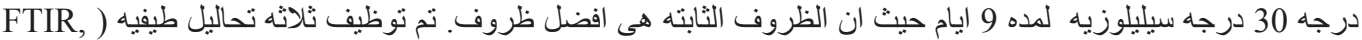

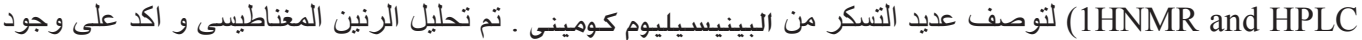

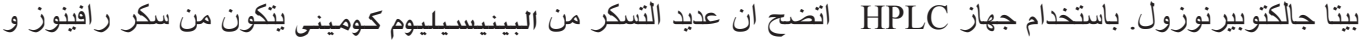

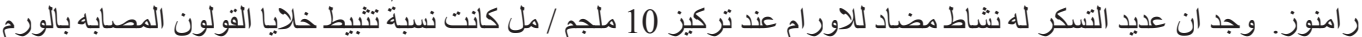

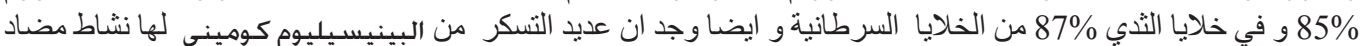

